TRAMES, 2009, 13(63/58), 1, 3-13

\title{
SEX DIFFERENCES IN READING ACHIEVEMENT
}

\author{
Richard Lynn ${ }^{1}$ and Jaan Mikk ${ }^{2}$ \\ ${ }^{1}$ University of Ulster and ${ }^{2}$ University of Tartu
}

\begin{abstract}
In the last century many studies have revealed the advantages of girls in reading and superiority of boys in science. However, the international tests detected no difference in science test results in the 21st century. The aim of the study was to find the sex effect size and variances in reading achievement in recent international studies. The analysis of PISA 2000, 2003, and 2006 data and the PIRLS 2001 and 2006 data revealed that the advantages in reading achievement of ten-year old girls was $0.23 d$ and that of 15 -year old girls was $0.42 d$. One explanation of girls' higher achievement in reading is in their deeper engagement in language related activities. Comparisons with other studies and possible implications are shown.
\end{abstract}

DOI: $10.3176 /$ tr.2009.1.01

Keywords: reading achievement, sex effect, meta-analysis, effect size, abilities

\section{Introduction}

It has frequently been asserted that women have higher average verbal abilities than men. For instance, "boys, from various cultures, are superior to girls on spatial problems; girls are superior to boys on verbal tasks" (Kagan 1971:182); "females are consistently superior to males in a wide range of verbal tasks" (Galsworthy et al. 2000:206); "the well attested fact that women are stronger on verbal items" (Bartholomew 2004:106); "it is well known that females have about a one-third of a standard deviation (5 IQ points) advantage over males" (Anderson 2004:828).

However, these assertions have not been universally accepted. In the metaanalysis of sex differences in verbal abilities in the United States by Hyde and Linn (1988) it was calculated that in pre-1973 studies girls had an advantage of $0.23 d$, while in post- 1973 studies it had dropped to $0.10 d$. But the girls' advantage of $0.10 d$ was only obtained by omitting the boys' advantage of $0.11 d$ of 18 year olds on the verbal SAT (Scholastic Assessment) in $1985(\mathrm{n}=977,361)$. Hyde and 
Linn (1988) also showed that the girls' advantage on verbal abilities varied according to age and the type of ability. In reading comprehension, girls below the age 6 performed better than boys $(0.31 d)$, but among older children the sex difference was negligible. In vocabulary, girls aged 6-10 years performed better than boys $(0.26 d)$, but among 11-18 year olds there was no difference, while among 19-25 year olds men performed better than women (0.23d). Analysis of sex differences by type of ability showed that women have higher average abilities in speech production (word fluency) (0.33d) and anagrams $(0.22 d)$, men have higher average abilities than women in analogies $(0.16 d)$, and there were negligible differences in reading comprehension, essay writing, and vocabulary.

Hyde and Linn's (1988) meta-analysis of sex differences in verbal abilities was a valuable contribution to this question. However, it was not complete. It omitted some data, such as all the Wechsler verbal intelligence studies and the study by Hogrebe, Nist, and Isadore (1985) who found no sex difference in reading achievement of 23,362 in-school seniors and 24,678 in-school sophomores in the results of High School and Beyond (HSB) national survey in 1980.

There have been some subsequent studies of sex differences in verbal abilities in the United States. Mau and Lynn (2000) analysed the tenth and twelfth graders' (16-18 year olds) test results in the American National Educational Longitudinal Study. They found that "females obtained significantly higher mean scores in reading." Klecker (2006:50) has made "a secondary analysis of the National Assessment of Educational Progress (NAEP) dataset ... for the fourth, eighth, and twelfth grade reading scores by students' sex across the years 1992, 1994, 1998, 2000, 2002, and 2003. The statistically significant $(\mathrm{p}<.01$ with effect size measured by Cohen's $d$ ) differences in reading scores by sex were consistent across grade level and years with females scoring higher than males." Effect sizes (0.13 to 0.44$)$ were smaller for the younger students. However, Jackson and Rushton (2006) reported a boys' advantage of 17/18 year olds of $0.10 d$ on the 1991 SAT $(\mathrm{n}=102,516)$. This replicated the result reported by Hyde and Linn's (1988). It is apparent, therefore, that the question of whether there are sex differences in verbal abilities is considerably more complex than the assertions quoted in the first paragraph of this paper suggest.

The studies reviewed above are all from the United States. It is important to investigate what the sex differences are internationally. A valuable contribution to this has been made recently by Lietz (2006). In a meta-analysis of sex differences in reading achievement in a number of countries she found that girls in secondary school performed 0.19 standard deviation units above boys.

The objective of the present paper is to make a further contribution to international sex differences in reading ability by examining sex differences in means and variances in the three PISA (Program for International Student Assessment carried out in 2000, 2003 and 2006) and two PIRLS studies, which provide extensive data on this question. The issue of sex differences in variances in reading ability has not been examined hitherto and is a further interesting component of this topic. 


\section{Data}

\subsection{The PISA 2000 study}

PISA tests measure reading, mathematical and scientific literacy level of students near the end of compulsory education. In 2000, the tests were carried out with 15 -year-olds in 27 countries. The total sample size was approximately 180,000 and includes around 5,000 students in each country. The results on reading comprehension consist of the scores on the test but in addition Wittmann (2005) has calculated latent factor scores by factor analysing the items. Both sets of scores are shown in Table 1 . The scores are presented as $d$ s (the difference between the means of boys and girls divided by the standard deviation), with positive $d$ s denoting higher mean scores obtained by girls. The raw scores show that girls scored higher than boys in all countries. The latent factor scores also show that girls obtained higher average scores than boys in all countries and magnify the girls' advantage.

Table 1. Sex differences in reading comprehension in the PISA 2000 study (ds)

\begin{tabular}{lcclcc}
\hline \multicolumn{1}{c}{ Country } & $\begin{array}{c}\text { Raw } \\
\text { score }\end{array}$ & $\begin{array}{c}\text { Latent } \\
\text { factor score }\end{array}$ & \multicolumn{1}{c}{ Country } & Raw score & $\begin{array}{c}\text { Latent factor } \\
\text { score }\end{array}$ \\
\hline Australia & 0.33 & 0.69 & Japan & 0.59 & 0.45 \\
Austria & 0.28 & 0.81 & Rep. of Korea & 0.56 & 0.41 \\
Belgium & 0.31 & 0.65 & Luxembourg & 0.65 & 0.52 \\
Canada & 0.35 & 0.65 & Mexico & 0.45 & 0.48 \\
Czech Rep. & 0.40 & 0.76 & New Zealand & 0.79 & 0.26 \\
Denmark & 0.26 & 0.63 & Norway & 0.93 & 0.49 \\
Finland & 0.60 & 0.91 & Poland & 0.72 & 0.38 \\
France & 0.32 & 0.74 & Portugal & 0.49 & 0.54 \\
Germany & 0.32 & 0.64 & Spain & 0.67 & 0.57 \\
Greece & 0.39 & 0.72 & Sweden & 0.66 & 0.27 \\
Hungary & 0.34 & 0.71 & Switzerland & 0.71 & 0.47 \\
Iceland & 0.44 & 0.68 & United Kingdom & 0.68 & 0.45 \\
Ireland & 0.31 & 0.73 & United States & 0.56 & 0.28 \\
Italy & 0.43 & 0.68 & Average & 0.49 & 0.58 \\
\hline
\end{tabular}

\subsection{The PISA 2003 study}

A second PISA study of 15 -year-olds in 40 countries was carried out in 2003. The results in reading comprehension are shown in Table 2 (Learning for Tomorrows World 2003, Table 6.3). It shows that in all countries girls obtained higher average scores than boys. The average advantage of the girls is $0.36 d$. The boys showed greater variance than the girls in all countries by an average variance ratio of 1.20 . 
Table 2. Sex differences in PISA 2003 and 2006 reading comprehension tests

\begin{tabular}{|c|c|c|c|c|c|c|c|}
\hline \multirow[b]{2}{*}{ Country } & \multicolumn{4}{|c|}{ PISA 2003} & \multicolumn{3}{|c|}{ PISA 2006} \\
\hline & $\begin{array}{l}\text { Boys' } \\
\text { mean } \\
\text { score }\end{array}$ & $\begin{array}{l}\text { Girls' } \\
\text { mean } \\
\text { score }\end{array}$ & $\begin{array}{c}\text { Effect } \\
\text { size } \\
(\mathrm{G}-\mathrm{B})\end{array}$ & $\begin{array}{c}\text { Variance } \\
\text { ratio } \\
(\mathrm{B} / \mathrm{G})\end{array}$ & $\begin{array}{l}\text { Boys' } \\
\text { mean }\end{array}$ & $\begin{array}{l}\text { Girls' } \\
\text { mean }\end{array}$ & $\begin{array}{c}\text { Effect } \\
\text { size }\end{array}$ \\
\hline Argentina & & & & & 345 & 399 & 0.43 \\
\hline Azerbaijan & & & & & 343 & 363 & 0.28 \\
\hline Australia & 506 & 545 & 0.41 & 1.25 & 495 & 532 & 0.39 \\
\hline Austria & 467 & 514 & 0.47 & 1.23 & 468 & 513 & 0.41 \\
\hline Belgium & 489 & 526 & 0.34 & 1.23 & 482 & 522 & 0.36 \\
\hline Brazil & 384 & 419 & 0.31 & 1.23 & 376 & 408 & 0.31 \\
\hline Bulgaria & & & & & 374 & 432 & 0.50 \\
\hline Canada & 514 & 546 & 0.36 & 1.26 & 511 & 543 & 0.33 \\
\hline Chile & & & & & 434 & 451 & 0.16 \\
\hline Chinese Taipei & & & & & 486 & 507 & 0.25 \\
\hline Colombia & & & & & 375 & 394 & 0.17 \\
\hline Croatia & & & & & 452 & 502 & 0.56 \\
\hline Czech Republic & 473 & 504 & 0.33 & 1.05 & 463 & 509 & 0.41 \\
\hline Denmark & 479 & 505 & 0.29 & 1.11 & 480 & 509 & 0.33 \\
\hline Estonia & & & & & 478 & 524 & 0.54 \\
\hline Finland & 521 & 565 & 0.56 & 1.26 & 521 & 572 & 0.62 \\
\hline France & 476 & 514 & 0.40 & 1.22 & 470 & 505 & 0.34 \\
\hline Germany & 471 & 513 & 0.39 & 1.19 & 475 & 517 & 0.38 \\
\hline Greece & 453 & 490 & 0.36 & 1.33 & 432 & 488 & 0.55 \\
\hline Hong Kong-China & 494 & 525 & 0.38 & 1.45 & 520 & 551 & 0.38 \\
\hline Hungary & 467 & 498 & 0.34 & 1.11 & 463 & 503 & 0.42 \\
\hline Iceland & 464 & 522 & 0.62 & 1.31 & 460 & 509 & 0.50 \\
\hline Indonesia & 369 & 394 & 0.32 & 1.00 & 384 & 402 & 0.24 \\
\hline Ireland & 501 & 530 & 0.34 & 1.09 & 500 & 534 & 0.37 \\
\hline Israel & & & & & 417 & 460 & 0.35 \\
\hline Italy & 455 & 495 & 0.40 & 1.31 & 448 & 489 & 0.38 \\
\hline Japan & 487 & 509 & 0.21 & 1.25 & 483 & 513 & 0.30 \\
\hline Jordan & & & & & 373 & 428 & 0.59 \\
\hline Korea & 525 & 547 & 0.26 & 1.09 & 539 & 574 & 0.40 \\
\hline Kyrgyzstan & & & & & 257 & 308 & 0.50 \\
\hline Latvia & 470 & 509 & 0.44 & 1.25 & 454 & 504 & 0.55 \\
\hline Liechtenstein & 517 & 534 & 0.19 & 1.18 & 486 & 531 & 0.47 \\
\hline Lithuania & & & & & 445 & 496 & 0.54 \\
\hline Luxembourg & 463 & 496 & 0.34 & 1.23 & 464 & 495 & 0.32 \\
\hline Macao-China & 491 & 504 & 0.20 & 1.18 & 479 & 505 & 0.34 \\
\hline Mexico & 389 & 410 & 0.23 & 1.07 & 393 & 427 & 0.35 \\
\hline Montenegro & & & & & 370 & 415 & 0.50 \\
\hline Netherlands & 503 & 524 & 0.25 & 1.08 & 495 & 519 & 0.25 \\
\hline New Zealand & 508 & 535 & 0.27 & 1.14 & 502 & 539 & 0.36 \\
\hline Norway & 475 & 525 & 0.49 & 1.26 & 462 & 508 & 0.44 \\
\hline Poland & 477 & 516 & 0.42 & 1.29 & 487 & 528 & 0.40 \\
\hline Portugal & 459 & 495 & 0.40 & 1.31 & 455 & 488 & 0.33 \\
\hline Qatar & & & & & 280 & 346 & 0.61 \\
\hline Romania & & & & & 374 & 418 & 0.48 \\
\hline Russian Federation & 428 & 456 & 0.31 & 1.28 & 420 & 458 & 0.41 \\
\hline Serbia & 390 & 433 & 0.55 & 1.28 & 381 & 422 & 0.45 \\
\hline Slovak Republic & 453 & 486 & 0.36 & 1.08 & 446 & 488 & 0.40 \\
\hline
\end{tabular}




\begin{tabular}{l|c|c|c|c|c|c|c}
\hline \multirow{2}{*}{ Country } & \multicolumn{4}{|c|}{ PISA 2003 } & \multicolumn{3}{c}{ PISA 2006 } \\
\cline { 2 - 8 } & $\begin{array}{c}\text { Boys' } \\
\text { mean } \\
\text { score }\end{array}$ & $\begin{array}{c}\text { Girls' } \\
\text { mean } \\
\text { score }\end{array}$ & $\begin{array}{c}\text { Effect } \\
\text { size } \\
(\mathrm{G}-\mathrm{B})\end{array}$ & $\begin{array}{c}\text { Variance } \\
\text { ratio } \\
(\mathrm{B} / \mathrm{G})\end{array}$ & $\begin{array}{c}\text { Boys' } \\
\text { mean }\end{array}$ & $\begin{array}{c}\text { Girls' } \\
\text { mean }\end{array}$ & $\begin{array}{c}\text { Effect } \\
\text { size }\end{array}$ \\
\hline Slovenia & & & & & 467 & 521 & 0.61 \\
Spain & 461 & 500 & 0.42 & 1.25 & 443 & 479 & 0.40 \\
Sweden & 496 & 533 & 0.39 & 1.11 & 488 & 528 & 0.41 \\
Switzerland & 482 & 517 & 0.38 & 1.15 & 484 & 515 & 0.33 \\
Thailand & 396 & 439 & 0.57 & 1.17 & 386 & 440 & 0.66 \\
Tunisia & 362 & 387 & 0.27 & 1.01 & 361 & 398 & 0.39 \\
Turkey & 426 & 459 & 0.36 & 1.28 & 427 & 471 & 0.47 \\
United Kingdom & & & & & 480 & 510 & 0.29 \\
United States & 479 & 511 & 0.32 & 1.17 & & & \\
Uruguay & 414 & 453 & 0.33 & 1.20 & 389 & 435 & 0.37 \\
Average & 463 & 497 & 0.36 & 1.20 & 440 & 479 & 0.41 \\
\hline
\end{tabular}

\subsection{The PISA 2006 study}

A third PISA study of 15-year-olds in 56 countries was carried out in 2006. The results in reading test are shown in Table 2 (PISA 2006, Table 6.1c) - in all countries girls obtained higher average scores than boys. The average advantage of the girls is $0.41 d$.

\subsection{The PIRLS 2001 reading study}

World-wide measurement of reading ability is carried out also by IEA International Association for the Evaluation of Educational Achievement. The association has assessed reading comprehension twice, in 2001 and in 2006. The first PIRLS study (Progress in International Reading Literacy Study) evaluated reading achievement of fourth grade students (10-year olds) in 35 countries (Mullis et al. 2003). In all countries, girls achieved significantly higher reading test results than boys. The sex effect size by countries is given in Table 3 (data from Mullis et al. 2003, Exhibit B. 2). In average, girls in fourth grade outperformed boys in reading by $0.25 d$. The variance of boys' results was larger than that of girls.

\subsection{The PIRLS 2006 reading study}

The study assessed children's reading literacy achievement and collected data about the impact of home environment on the achievement. The study was conducted in 40 countries and about four-five thousand students participated in every country. Relying on the submitted data (Mullis et al., 2007, Exhibit C. 2), the superiority of girls in reading can be calculated (Table 3). The average sex effect size $(d=0.21)$ is almost the same as in previous study and the variance in boys' results is once more larger by eight percent. 
Table 3. Sex effect on international reading achievement in the PIRLS studies

\begin{tabular}{|c|c|c|c|c|c|c|c|c|c|c|c|c|}
\hline \multirow[t]{2}{*}{ Country } & \multicolumn{6}{|c|}{ PIRLS 2001} & \multicolumn{6}{|c|}{ PIRLS 2006} \\
\hline & $\begin{array}{l}\text { Girls' } \\
\text { mean }\end{array}$ & $\begin{array}{c}\text { Girls' } \\
\text { SD }\end{array}$ & $\begin{array}{l}\text { Boys' } \\
\text { mean }\end{array}$ & $\begin{array}{c}\text { Boys' } \\
\text { SD }\end{array}$ & \begin{tabular}{|c|} 
Effect \\
size \\
G-B
\end{tabular} & $\begin{array}{l}\text { Var. } \\
\text { ratio } \\
\mathrm{B} / \mathrm{G}\end{array}$ & $\begin{array}{l}\text { Girls' } \\
\text { mean }\end{array}$ & $\begin{array}{c}\text { Girls } \\
\text { SD }\end{array}$ & $\begin{array}{l}\text { Boys' } \\
\text { mean }\end{array}$ & $\begin{array}{c}\text { Boys' } \\
\text { SD }\end{array}$ & $\begin{array}{c}\text { Effect } \\
\text { size } \\
\text { G-B }\end{array}$ & $\begin{array}{c}\text { Var. } \\
\text { ratio } \\
\mathrm{B} / \mathrm{G}\end{array}$ \\
\hline Argentina & 428 & 96 & 410 & 94 & 0.19 & 0.96 & & & & & & \\
\hline Austria & & & & & & & 543 & 62 & 533 & 65 & 0.16 & 1.10 \\
\hline Belgium Flemish & & & & & & & 550 & 54 & 544 & 57 & 0.11 & 1.11 \\
\hline Belgium French & & & & & & & 502 & 67 & 497 & 70 & 0.07 & 1.09 \\
\hline Belize & 341 & 105 & 314 & 104 & 0.26 & 0.98 & & & & & & \\
\hline Bulgaria & 562 & 79 & 538 & 85 & 0.29 & 1.16 & 558 & 80 & 537 & 84 & 0.26 & 1.10 \\
\hline Canada, Alberta & & & & & & & 564 & 67 & 556 & 67 & 0.12 & 1.00 \\
\hline $\begin{array}{l}\text { Canada, British } \\
\text { Columbia }\end{array}$ & & & & & & & 562 & 68 & 554 & 70 & 0.12 & 1.06 \\
\hline $\begin{array}{l}\text { Canada, Nova } \\
\text { Scotia }\end{array}$ & & & & & & & 553 & 73 & 531 & 78 & 0.29 & 1.14 \\
\hline Canada, Ontario & & & & & & & 562 & 68 & 549 & 72 & 0.19 & 1.12 \\
\hline Canada, Quebec & & & & & & & 539 & 61 & 527 & 65 & 0.19 & 1.14 \\
\hline Canada $(O, Q)$ & 553 & 71 & 536 & 72 & 0.24 & 1.03 & & & & & & \\
\hline Chinese Taipei & & & & & & & 542 & 62 & 529 & 66 & 0.20 & 1.13 \\
\hline Colombia & 428 & 82 & 416 & 79 & 0.15 & 0.93 & & & & & & \\
\hline Cyprus & 506 & 79 & 482 & 82 & 0.30 & 1.08 & & & & & & \\
\hline Czech Republic & 543 & 62 & 531 & 66 & 0.19 & 1.13 & & & & & & \\
\hline Denmark & & & & & & & 553 & 69 & 539 & 69 & 0.20 & 1.00 \\
\hline England & 564 & 84 & 541 & 88 & 0.27 & 1.10 & 549 & 87 & 530 & 86 & 0.22 & 0.98 \\
\hline France & 531 & 69 & 520 & 71 & 0.16 & 1.06 & 527 & 65 & 516 & 67 & 0.17 & 1.06 \\
\hline Georgia & & & & & & & 480 & 73 & 463 & 76 & 0.23 & 1.08 \\
\hline Germany & 545 & 67 & 533 & 67 & 0.18 & 1.00 & 551 & 66 & 544 & 68 & 0.10 & 1.06 \\
\hline Greece & 535 & 69 & 514 & 76 & 0.29 & 1.21 & & & & & & \\
\hline Hong Kong, SAR & 538 & 59 & 519 & 65 & 0.31 & 1.21 & 569 & 56 & 559 & 61 & 0.17 & 1.19 \\
\hline Hungary & 550 & 64 & 536 & 67 & 0.21 & 1.10 & 554 & 70 & 548 & 70 & 0.09 & 1.00 \\
\hline Iceland & 522 & 72 & 503 & 76 & 0.26 & 1.11 & 520 & 65 & 501 & 70 & 0.28 & 1.16 \\
\hline Indonesia & & & & & & & 415 & 76 & 395 & 80 & 0.26 & 1.11 \\
\hline $\begin{array}{l}\text { Iran, Islamic } \\
\text { Rep. of }\end{array}$ & 426 & 91 & 399 & 92 & 0.30 & 1.02 & 429 & 94 & 414 & 95 & 0.16 & 1.02 \\
\hline Israel & 520 & 90 & 498 & 96 & 0.24 & 1.14 & 520 & 96 & 506 & 101 & 0.14 & 1.11 \\
\hline Italy & 545 & 71 & 537 & 71 & 0.11 & 1.00 & 555 & 67 & 548 & 68 & 0.10 & 1.03 \\
\hline Kuwait & 422 & 81 & 373 & 90 & 0.57 & 1.23 & 364 & 101 & 297 & 109 & 0.64 & 1.16 \\
\hline Latvia & 556 & 61 & 534 & 60 & 0.36 & 0.97 & 553 & 60 & 530 & 63 & 0.37 & 1.10 \\
\hline Lithuania & 552 & 63 & 535 & 64 & 0.27 & 1.03 & 546 & 56 & 528 & 56 & 0.32 & 1.00 \\
\hline Luxembourg & & & & & & & 559 & 66 & 556 & 67 & 0.05 & 1.03 \\
\hline $\begin{array}{l}\text { Macedonia, } \\
\text { Rep. of }\end{array}$ & 452 & 103 & 431 & 102 & 0.20 & 0.98 & 453 & 101 & 432 & 100 & 0.21 & 0.98 \\
\hline Moldova, Rep. of & 504 & 71 & 479 & 77 & 0.34 & 1.18 & 507 & 67 & 493 & 70 & 0.20 & 1.09 \\
\hline Morocco & 361 & 115 & 341 & 115 & 0.17 & 1.00 & 332 & 106 & 314 & & & \\
\hline Netherlands & 562 & 56 & 547 & 58 & 0.26 & 1.07 & 551 & 53 & 543 & 53 & 0.15 & 1.00 \\
\hline New Zealand & 542 & 90 & 516 & 95 & 0.28 & 1.11 & 544 & 81 & 520 & 90 & 0.28 & 1.23 \\
\hline Norway & 510 & 77 & 489 & 83 & 0.26 & 1.16 & 508 & 64 & 489 & 67 & 0.29 & 1.10 \\
\hline Poland & & & & & & & 528 & 74 & 511 & 76 & 0.23 & 1.05 \\
\hline Qatar & & & & & & & 372 & 90 & 335 & 97 & 0.40 & 1.16 \\
\hline Romania & 519 & 87 & 504 & 92 & 0.17 & 1.12 & 497 & 91 & 483 & 92 & 0.15 & 1.02 \\
\hline
\end{tabular}




\begin{tabular}{|c|c|c|c|c|c|c|c|c|c|c|c|c|}
\hline \multirow[t]{2}{*}{ Country } & \multicolumn{6}{|c|}{ PIRLS 2001} & \multicolumn{6}{|c|}{ PIRLS 2006} \\
\hline & $\begin{array}{l}\text { Girls' } \\
\text { mean }\end{array}$ & $\begin{array}{c}\text { Girls' } \\
\text { SD }\end{array}$ & $\begin{array}{c}\text { Boys' } \\
\text { mean }\end{array}$ & $\begin{array}{c}\text { Boys' } \\
\text { SD }\end{array}$ & $\begin{array}{c}\text { Effect } \\
\text { size } \\
\text { G-B }\end{array}$ & $\begin{array}{c}\text { Var. } \\
\text { ratio } \\
\text { B/G }\end{array}$ & $\begin{array}{l}\text { Girls' } \\
\text { mean }\end{array}$ & $\begin{array}{l}\text { Girls } \\
\text { ' SD }\end{array}$ & $\begin{array}{l}\text { Boys' } \\
\text { mean }\end{array}$ & $\begin{array}{c}\text { Boys' } \\
\text { SD }\end{array}$ & $\begin{array}{c}\text { Effect } \\
\text { size } \\
\text { G-B }\end{array}$ & $\begin{array}{l}\text { Var. } \\
\text { ratio } \\
\mathrm{B} / \mathrm{G}\end{array}$ \\
\hline $\begin{array}{l}\text { Russian } \\
\text { Federation }\end{array}$ & 534 & 65 & 522 & 67 & 0.18 & 1.06 & 572 & 67 & 557 & 69 & 0.22 & 1.06 \\
\hline Scotland & 537 & 83 & 519 & 84 & 0.22 & 1.02 & 538 & 78 & 516 & 80 & 0.28 & 1.05 \\
\hline Singapore & 540 & 88 & 516 & 94 & 0.26 & 1.14 & 567 & 73 & 550 & 79 & 0.22 & 1.17 \\
\hline Slovak I & 526 & 68 & 510 & 72 & 0.23 & 1.12 & 537 & 73 & 525 & 75 & 0.16 & 1.06 \\
\hline Slovenia & 512 & 69 & 491 & 73 & 0.30 & 1.12 & 532 & 67 & 512 & 73 & 0.29 & 1.19 \\
\hline South Africa & & & & & & & 319 & 136 & 283 & 134 & 0.27 & 0.97 \\
\hline Spain & & & & & & & 515 & 71 & 511 & 71 & 0.06 & 1.00 \\
\hline Sweden & 572 & 63 & 550 & 67 & 0.34 & 1.13 & 559 & 62 & 541 & 64 & 0.29 & 1.07 \\
\hline $\begin{array}{l}\text { Trinidad and } \\
\text { Tobago }\end{array}$ & & & & & & & 451 & 98 & 420 & 106 & 0.30 & 1.17 \\
\hline Turkey & & & 440 & 87 & & 1.07 & & & & & & \\
\hline United States & & 79 & 533 & 86 & 0.22 & 1.19 & 545 & 71 & 535 & 77 & 0.14 & 1.18 \\
\hline Mean & 510 & 78 & 490 & 80 & 0.25 & 1.08 & 514 & 74 & 498 & 77 & 0.21 & 1.08 \\
\hline
\end{tabular}

\section{Why do girls have higher reading ability?}

Marks has recently (2008) studied the problem. He found that higher achievement of girls in reading and mathematics is associated with the school system factors and macro-societal factors. We searched the living conditions and activities of girls and boys to find some explanation to the higher test scores of girls. The data for the comparison were taken from the PISA online database (http://pisa2006.acer.edu.au/). The student questionnaire included relatively few questions whose answers might correlate with the results of reading test, however, some interesting information can be found in Table 4. The table includes the numbers of girls and boys who selected the given answer in their questionnaire in all 56 countries. The percentages have been calculated in relation to the overall number of girls and boys who took the test. Significance test was applied to the percentages. All the differences are statistically significant although many of them are minor.

We see in the table that boys have more often their own room than girls. This is fully unexpected and does not explain why girls had a higher score in the reading test. Boys have more often also DVR or VCR players. This may take time from reading and contribute to lower scores. Boys have a little bit more books at home but nevertheless they are not so good in reading.

Girls have a little bit more often their own study desk that may contribute to their higher reading test results. According to the evaluation of girls, there is more classic literature and poetry in their homes. Children influence the home culture and so this literature is bought more often for girls. More girls are from homes without a computer. Working on computers may reduce the boys' time for reading books and magazines. 
Table 4. Some differences in living conditions and activities of girls and boys according to PISA 2006 data

\begin{tabular}{l|l|r|r|r|r|r}
\hline \multirow{2}{*}{$\begin{array}{c}\text { Question } \\
\text { No }\end{array}$} & \multicolumn{1}{c|}{ PISA 2006 characteristic } & \multicolumn{2}{c|}{ Number of } & \multicolumn{2}{c}{ Percentage } & \multirow{2}{*}{$\mathrm{t}$} \\
\cline { 3 - 5 } & & Girls & Boys & G & B & \\
\hline ST4 & Number of participants & 196989 & 192504 & 100 & 100 & 0.00 \\
ST13Q02 & Possession own room & 148453 & 151625 & 75 & 79 & -19.26 \\
ST13Q14 & Possession DVD or VCR player & 169283 & 168525 & 86 & 88 & -8.08 \\
ST13Q01 & Possession desk & 172464 & 167323 & 88 & 87 & 3.15 \\
ST13Q08 & Possessions classic literature & 110146 & 96722 & 56 & 50 & 46.63 \\
ST13Q09 & Possession poetry & 115712 & 91930 & 59 & 48 & 90.41 \\
ST14Q03 & No computer & 44659 & 38295 & 23 & 20 & 57.01 \\
ST15Q01 & Over 100 books at home & 70876 & 70876 & 36 & 37 & -10.04 \\
ST31Q07 & Regular lessons in language & 92378 & 77951 & 47 & 40 & 64.04 \\
ST31Q08 & No out of school lesson in language & 107653 & 104224 & 55 & 54 & 4.07 \\
ST31Q09 & Less than 2 hours language self study & 118110 & 131012 & 60 & 68 & -55.27 \\
ST36Q03 & Self assessment: Do well in Language & 171935 & 152214 & 87 & 79 & 43.08 \\
\hline
\end{tabular}

In school, girls have more regular lessons in language. This could contribute to their higher test results in reading. However, a little bit more girls have no out of school language lessons. We may suppose that families do not consider it important to pay money for girls to have out of school lessons. Anyway, this does not impair their reading. More girls are confident that they are doing well in language. The self-evaluation supports learning language and is a result of good learning.

There are more boys among students who have fewer than 2 hours for selfstudy of language. Once more girls devote more time to language studies and boys have other interests.

\section{Discussion}

The three PISA studies with 15-year old students all show that girls obtain higher average scores than boys in reading ability. In 2000, 2003 and 20006 the girls' advantage was $0.49 d, 0.36 d$, and $0.41 d$, respectively. These can be averaged to $0.42 d$. In the PIRLS studies with 10-year-olds, the sex effect in favour of girls was $0.25 d$ in 2001 and $0.21 d$ in 2006 or $0.23 d$ in average. The girls' superiority grows with age and practising language.

Both of our effect sizes are substantially greater than the $0.19 d$ calculated by Lietz in her meta-analysis (2006). Reading ability as defined in the PISA studies is essentially the same as the concept of verbal comprehension used by psychologists as a component of intelligence, and for which Hyde and Linn (1988) found in their meta-analysis of American studies that the average sex difference was 0.14d.

One explanation of the very big advantages of 15-year-old girls is that PISA test usually indicates a rather large difference in boys' and girls' results. In the above-mentioned meta-analysis by Lietz, the sex effect size for PISA test was 
0.25d (Lietz, 2006:334). However, the sex effect is even bigger in recent PISA studies and this leads to the idea that girls' superiority in reading is rising.

Last year a new study of sex differences in science attainment was published (Lynn and Mikk 2008). The study confirmed boys' superiority in science that was bigger in the seventies than in recent ten years, when it was negligible. According to PISA studies in 2000, 2003, and 2006, there was no difference in average science attainment of 15-year-old girls and boys but girls outperformed boys by $0.42 d$ in reading. According to OECD studies in 2001, 2003, and 2006, girls were as good in science as boys were, but girls outperformed boys in reading by $0.23 d$. Marks (2008) recently found analogous trends for sex cap in mathematics and reading. Hyde et al. (2008:494) have studied standardized test results in the U.S. and conclude "that girls now score just as well as boys in math". In these areas together, girls have an advantage. What might be the reasons?

The correlates of academic achievement have been presented in very many studies, including PISA (Mullis et al. 2003; 2007). Relying on this knowledge, we searched and found some differences in living conditions and activities of girls and boys. Girls were reading more at home and school; boys were busy with computers and DVD players. Interests are related to activities and achievement. The inference is supported by the conclusions of Chiu and McBridge-Chang (2006:331) who found analyzing the PISA 2000 data that "reading enjoyment mediated $42 \%$ of the gender effect" on reading achievement.

The advantage of girls in reading leads to the preference of professions in which reading and writing are an important part of a job. There are more women in the professions of social sphere because they have higher verbal abilities than men have in general. For example, we have so many female teachers because men are not so well fitted for the job.

The explanation above is only one aspect in the complicated process of selecting a profession. It is insufficient in explaining, for example, why there are more men among politicians than women. Variance ratios in reading achievement add another aspect into the explanation.

We found sex differences in the variance of reading achievement in all three studies analysed. The biggest variance ratio 1.20 was in the PISA 2003 study and it was 1.08 in both PIRLS studies. In the PISA study, boys showed greater variance in reading comprehension than the girls in all countries, and in the PIRLS studies, the boys' variance was larger in most countries. Analogous results in the variability of achievement were found for international science tests (Lynn and Mikk 2008).

This is consistent with the frequent assertion that men have greater variability of intelligence than women, i.e. there are more men with high and low intelligence, while women cluster around the mean. This contention was advanced in the early years of the twentieth century by Ellis (1904), Thorndike (1910) and Terman (1916) to explain why men are so greatly over-represented among geniuses. When they found that there is no sex difference in general intelligence, a greater variability among men entailing more men among those with very high 
intelligence (as well as more men with very low intelligence) seemed to provide a solution to this problem. Many subsequent scholars have continued to advance this contention, e.g. Eysenck (1981:42), and Deary et al. (2007). The present results from the PISA and PIRLS studies provide further confirmation.

However, the reasons for greater variability among men are still not understood. We may just hypothesise that women have greater responsibility in bringing up the new generation and the fulfilment of this important task may be in danger in the case of big variability which sometimes is a disadvantage in life.

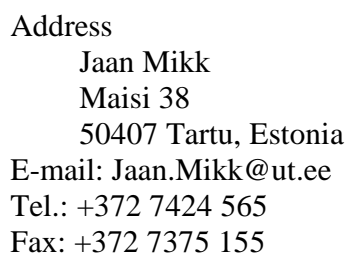

\section{References}

Anderson, Michael (2004) "Sex differences in general intelligence". In The Oxford companion to the mind. R. L. Gregory, ed. Oxford, UK: Oxford University Press.

Bartholomew, David J. (2004) Measuring intelligence: facts and fallacies. Cambridge: Cambridge University Press.

Chiu, Ming Ming and Catherine McBride-Chang (2006)."Gender, context, and reading: a comparison of students in 43 countries". Scientific Studies of Reading 10, 4, 331-362.

Deary, Ian J., Paul Irwing, Geoff Der, and Timothy C. Bates (2007) "Brother-sister differences in the g factor in intelligence: analysis of full, opposite-sex siblings from the NLSY 1970". Intelligence 35, 451-456.

Ellis, Havelock. (1904) Man and woman: a study of human secondary sexual characteristics. London: Walter Scott.

Eysenck, Hans Jurgen (1981) Intelligence: battle for the mind. London: Pan.

Galsworthy, Michael J., Robert Plomin, Ginette Dionne, and Philip S. Dale (2000) "Sex differences in early verbal and non-verbal cognitive development”. Developmental Science 3, 206-215.

Hogrebe, Mark C., Sherrie L. Nist, and Isadore Newman (1985) "Are there gender differences in reading achievement? An investigation using the high school and beyond data". Journal of Educational Psychology 77, 6, 716-724.

Hyde, Janet S., Sara M. Lindberg, Marcia C., Linn, Any B. Ellis, and Caroline C. Williams (2008) "Gender similarities characterize math performance". Science 321, 494-495.

Hyde, Janet S. and Marcia C. Linn (1988) "Gender differences in verbal ability: a meta-analysis". Psychological Bulletin 104, 1, 53-69.

Jackson, Douglas N. and J. Philippe Rushton (2006) "Males have greater g: sex differences in general mental ability from 100,000 17-18 year olds on the Scholastic Assessment Test". Intelligence 34, 479-486.

Kagan, Jerome (1971) Change and continuity in infancy. New York: John Wiley.

Klecker, Beverly. M. (2006) "The gender gap in NAEP fourth-, eighth-, and twelfth-grade reading scores across years". Reading Improvement 43, 1, 50-56.

Learning for tomorrow's world - first results from PISA 2003. Retrieved May 21, 2008 from http://www.pisa.oecd.org/document/55/0,3343,en_32252351_32236173_33917303_1_1_1_1 ,00.html 
Lietz, Petra (2006) "A meta-analysis of gender differences in reading achievement at the secondary school level". Studies in Educational Evaluation 32, 4, 317-344.

Lynn Richard and Jaan Mikk (2008) "Science: sex differences in attainment". The Journal of Social, Political and Economic Studies 33, 1, 101-124.

Marks, Gary N. (2008) "Accounting for the gender gaps in student performance in reading and mathematics: evidence from 31 countries". Oxford Review of Education 34, 1, 89-109.

Mau, Wei-Cheng and Richard Lynn. (2000) "Gender differences in homework and test scores in mathematics, reading and science at tenth and twelfth grade". Psychology, Evolution \& Gender 2, 2, 119-125.

Mullis, Ina V. S., Michael O. Martin, Eugenio J., Gonzalez, and Ann M. Kennedy (2003) PIRLS 2001 international report: IEA's study of reading literacy achievement in primary schools. Chestnut Hill, MA: Boston College. Retrieved May 20, 2008, from http://pirls.bc.edu/ pirls2001i/PIRLS2001_Pubs_IR.html

Mullis, Ina V. S., Michael O. Martin, Ann M. Kennedy, and P. Foy (2007) IEA's progress in international reading literacy study in primary school in 40 countries. Chestnut Hill, MA: TIMSS \& PIRLS International Study Center, Boston College. Retrieved May 21, 2008, from http://pirls.bc.edu/pirls2006/intl_rpt.html

PISA 2006: science competencies for tomorrow's world. Retrieved on May 21, 2008, from http://www.oecd.org/document/2/0,3343,en_32252351_32236191_39718850_1_1_1_1,00.html

Terman, Lewis M. (1916) The measurement of intelligence. New York: Houghton Mifflin.

Thorndike, Edward L. (1910) Educational psychology. New York: Houghton Mifflin.

Wittmann, Walter W. (2005) "Group differences in intelligence and related matters". In Handbook of understanding and measuring intelligence. O. Wilhelm and R. Engle, eds. London: Thousand Oaks. 